\title{
Bone Quality in Female Ballet Dancers: A Possible Determinant of Bone Health
}

\author{
Hiroki Funasaki ${ }^{*}$, Mitsuru Saito², Mayumi Kuno-Mizumura3 ${ }^{3}$, Hiroteru Hayashi', \\ Keishi Marumo²
}

\author{
${ }^{1}$ Department of Sports and Wellness Clinic, Jikei University School of Medicine, Tokyo, Japan \\ ${ }^{2}$ Department of Orthopaedic Surgery, Jikei University School of Medicine, Tokyo, Japan \\ ${ }^{3}$ Graduate School of Humanities and Sciences, Ochanomizu University, Tokyo, Japan \\ Email: *funasaki@jikei.ac.jp
}

How to cite this paper: Funasaki, H., Saito, M., Kuno-Mizumura, M., Hayashi, H. and Marumo, K. (2017) Bone Quality in Female Ballet Dancers: A Possible Determinant of Bone Health. Open Journal of Orthopedics, 7, 284-293.

https://doi.org/10.4236/ojo.2017.79028

Received: August 22, 2017

Accepted: September 22, 2017

Published: September 25, 2017

Copyright $\odot 2017$ by authors and Scientific Research Publishing Inc. This work is licensed under the Creative Commons Attribution International License (CC BY 4.0).

http://creativecommons.org/licenses/by/4.0/

(c) (i) Open Access

\begin{abstract}
Hypotheses: Values of serum markers related to bone quality are abnormal in young female ballet dancers. Methods: In 13 elite Japanese female ballet dancers (average age, 22 years), markers related to bone quality were investigated. These included: serum homocystein (HC), a marker of increased oxidative stress; pentosidine (Pent), a marker of glycation- or oxidation-induced non-enzymatic cross-links; markers of bone metabolism (bone alkaline phosphatase, BAP; tartrate-resistant acid phosphatase 5b, TRAP5b) and bone mineral density (BMD). It was determined whether there is a relationship between bone quality markers' levels are related to amenorrhea and/or fatigue fractures. Results: Two dancers had fatigue fractures and 3 had a history of secondary amenorrhea. The average BMD was $1.305 \pm 0.12\left(\mathrm{~g} / \mathrm{cm}^{2}\right)$, in all these cases the Z-score was higher than -1.0. Although the serum levels of BAP, TRAP5b, and HC were normal in all examined dancers, in 2 out of 3 dancers with a history of secondary amenorrhea, pentosidine serum levels were increased. No relationship between bone quality markers' levels and fatigue fractures was found. Conclusion: Latent deterioration of bone quality may occur in female athletes with secondary amenorrhea and otherwise normal BMD and calcium metabolism markers.
\end{abstract}

\section{Keywords}

Bone Quality, Bone Mineral Density, Female Athletes, Ballet Dancer

\section{Introduction}

The position stand, introduced by the American College of Sports Medicine (ACSM), defined the female athlete triad (FAT) as low energy availability, ame- 
norrhea and osteoporosis [1] [2]. FAT can be clinically manifested by stress fractures. It has been recently addressed by the International Olympic Committee (IOC), and focus was mainly on relative energy deficiency in FAT [3] [4]. In regard to bone health, the position stands have related only to bone mineral density (BMD), but BMD is only one of bone strength indicators: even amongst patients with the same BMD values, fractures develop only in few. Recent studies indicate that not only BMD but also bone quality seems to play an important role in bone strength by its direct relationship with collagen cross-link formation [3] [5] [6] [7] [8] [9]. Collagen cross-links can be divided into physiological enzymatic cross-links and non-physiological oxidative stress-induced crosslinks, the latter including advanced glycation end products (AGEs) such as pentosidine (Pent). In osteoporotic patients, serum levels of homocystein (HC), a marker of increased oxidative stress, and Pent have been widely used as determinants of bone quality [6] [7] [10]-[15]; however, no studies have been performed on status of bone quality in young female athletes.

The purpose of this study was to evaluate bone quality in elite female ballet dancers by measuring serum HC and Pent levels as well as BMD and bone metabolism markers, and to determine whether these markers show any relationship with amenorrhea and/or fatigue fractures.

\section{Methods}

\subsection{Subjects}

Inclusion criteria were the dancers 1): their age was 20 years old or over, 2): their training experience was 10 years or more, and 3): their training frequency was more than five days in a week. Out of 20 top-leveled female ballet dancers of the Ochanomizu University in Tokyo, Japan, who filled the above criteria, 13 dancers (mean and SD; age: $21.8 \pm 2.0$ years; body mass: $49 \pm 6.3 \mathrm{~kg}$; height: $160.7 \pm$ $6.4 \mathrm{~cm}$ and BMI $18.8 \pm 1.2 \mathrm{~kg} \cdot \mathrm{m}^{-2}$ ) with an average 15.8 years of training experience agreed to participate in this study. All subjects signed a written informed consent. The ethic committees of Jikei University (No. 23-026) and Ochanomizu University (No. 23-3) approved the study design.

\subsection{Body Health Questionnaire (History of Fatigue Fracture and Menstrual Cycle Status)}

The dancers were asked to fill a health status questionnaire, which included questions on history of fatigue fractures, menstrual history and cycle characteristics, history of other diseases and drug use, including oral contraceptive agents. A regular cycle was defined as menstrual periods occurring every 21 to 35 days. Primary amenorrhea was defined as absence of menarche by the age of 15 years and secondary amenorrhea as cessation of menses for three or more consecutive cycles after the menarche onset. Oligomenorrhea was defined as menstrual bleeding occurring at intervals longer than 35 days [2] [16] [17]. Fatigue fracture was defined as being diagnosed by an orthopedic surgeon, and the 
questionnaire included questions on time of fracture and affected bone.

\subsection{Bone Mineral Density (BMD)}

BMD of the lumbar spine (L1-L4) was examined by dual-energy X-ray absorptiometry (DXA) (GE Lunar Prodigy densitometer, Version 10.51; Madison, Wisconsin) and body composition was also assessed. The daily coefficient of variation of the calibration phantom over a 6 -month period was $0.16 \%$. The International Society for Clinical Densitometry (ISCD), World Health Organization (WHO), and ACSM classification systems were used to define low BMD based on Z-scores.

\subsection{Blood Sampling}

Blood samples were obtained by venipuncture in the afternoon and the following serum parameters were measured: 1) serum bone metabolic markers: bone alkaline phosphatase (BAP) and tartrate-resistant acid phosphatase 5b (TRAP5b); 2) bone quality-related markers: $\mathrm{HC}$ and Pent; 3) thyroid-stimulating hormone (TSH), intact parathyroid hormone (iPTH) and adrenocorticotropic hormone (ACTH) to exclude endocrinologic disturbances potentially involved in regulation of calcium metabolism. All blood examinations were carried out at the SRL laboratory (Tokyo, Japan) accordingly with the previously reported methods [18].

\subsection{Statistical Analysis}

Database construction and statistical analyses were performed using SPSS for Windows (version 19, IBM Corp). Continuous variables were expressed as mean \pm SD. Pearson product moment correlation coefficients were computed to determine a relationship between BMD and Pent. Statistical significance was set at $\mathrm{p} \leq 0.05$.

\section{Results}

\subsection{History of Fatigue Fractures}

Two ballet dancers had a history of fatigue fracture: one developed bilateral pars-interarticularis fracture of the $4^{\text {th }}$ lumbar spine (spondylolysis) (case No. 4) and the other suffered from a tibial fracture (case No. 9). They occurred 8 and 14 years before commencement of the study, respectively, and were conservatively treated (Table 1 and Table 2).

\subsection{History of Menstrual Dysfunction}

The onset age of menarche was from 11 to 15 years, 12.8 years in average. Three subjects had a history of secondary amenorrhea (cases No. 3, 6, 10); in these cases, the age at menarche cessation was 19, 18 and 17 years, respectively. The duration of amenorrhea was 2 years in all subjects. In case 6 , the dancer continuously suffered from amenorrhea until the time of present study. Overall, 4 
Table 1. Subjects' characteristics (1).

\begin{tabular}{|c|c|c|c|c|c|c|}
\hline Case No. & $\begin{array}{c}\text { Age } \\
\text { (years old) }\end{array}$ & Height $(\mathrm{cm})$ & Weight $(\mathrm{kg})$ & $\begin{array}{l}\mathrm{BMI}^{* *} \\
\left(\mathrm{~kg} / \mathrm{m}^{2}\right)\end{array}$ & $\begin{array}{c}\text { Training } \\
\text { Experience (years) }\end{array}$ & $\begin{array}{l}\text { Age at first } \\
\text { menarche }\end{array}$ \\
\hline 1 & 21 & 164 & 53 & 19.7 & 14 & 13 \\
\hline 2 & 23 & 160 & 47 & 18.4 & 15 & 12 \\
\hline 3 & 21 & 162 & 54 & 20.5 & 18 & 14 \\
\hline 4 & 22 & 158 & 47 & 18.9 & 13 & 14 \\
\hline 5 & 24 & 159 & 46 & 18.1 & 19 & 12 \\
\hline 6 & 20 & 149 & 40 & 17.8 & 16 & 12 \\
\hline 7 & 20 & 152 & 42 & 18.1 & 10 & 11 \\
\hline 8 & 20 & 163 & 48 & 18 & 16 & 13 \\
\hline 9 & 27 & 169 & 51 & 17.8 & 24 & 15 \\
\hline 10 & 21 & 158 & 49 & 19.5 & 13 & 11 \\
\hline 11 & 21 & 174 & 65 & 21.5 & 16 & 14 \\
\hline 12 & 21 & 161 & 50 & 19.2 & 15 & 11 \\
\hline 13 & 22 & 161 & 45 & 17.3 & 17 & 15 \\
\hline Mean & 21.8 & 160.8 & 49 & 18.8 & 15.8 & 12.8 \\
\hline S.D $D^{*}$ & 2 & 6.4 & 6.2 & 1.2 & 3.4 & 1.5 \\
\hline
\end{tabular}

* Standard Deviation ${ }^{* *}$ Body Mass Index.

Table 2. Subjects' characteristics (2).

\begin{tabular}{|c|c|c|c|c|c|}
\hline Case No. & $\begin{array}{c}\text { Fatigue fracture } \\
\text { (location) }\end{array}$ & $\begin{array}{c}\text { Secondary } \\
\text { amenorrhea }\end{array}$ & $\begin{array}{c}\text { Period of } \\
\text { amenorrhea } \\
\text { (years of age) }\end{array}$ & $\begin{array}{l}\mathrm{BMD}^{\star *} \\
\left(\mathrm{~g} / \mathrm{cm}^{2}\right)\end{array}$ & Z-score \\
\hline 1 & - & no & - & 1.397 & 1.4 \\
\hline 2 & - & no & - & 1.232 & 1.4 \\
\hline 3 & - & yes & $19 \sim 21$ & 1.402 & 1.9 \\
\hline 4 & 4th lumbar & no & - & 1.238 & 1.1 \\
\hline 5 & - & no & - & 1.302 & 1.6 \\
\hline 6 & - & yes & $18 \sim 20$ & 1.064 & 0 \\
\hline 7 & - & no & - & 1.288 & 1.7 \\
\hline 8 & - & no & - & 1.226 & 0.9 \\
\hline 9 & Tibia & no & - & 1.416 & 2.2 \\
\hline 10 & - & yes & $17 \sim 19$ & 1.36 & 1.9 \\
\hline 11 & - & no & - & 1.356 & 0.9 \\
\hline 12 & - & no & - & 1.518 & 3.1 \\
\hline 13 & - & no & - & 1.164 & 0.5 \\
\hline Mean & & & & 1.305 & 1.43 \\
\hline S.D ${ }^{*}$ & & & & 0.121 & 0.79 \\
\hline
\end{tabular}

* Standard Deviation ${ }^{* *}$ Bone mineral density. 
subjects considered their menstrual cycles as irregular in the questionnaire (3 cases with amenorrhea and one case without, case No. 12).

\subsection{BMD}

BMD ranged from 1.064 to $1.518 \mathrm{~g} / \mathrm{cm}^{2}$ and averaged $1.305 \pm 0.121 \mathrm{~g} / \mathrm{cm}^{2}$. T-score was from -0.6 to 3.1 (1.34 in average), and Z-score was from 0 to 3.1 (1.43 in average), in all dancers the scores were higher than -2.5 and -1.0 , for $T$ and Z-score, respectively.

\subsection{Serum Bone Metabolic Markers (BAP, TRAP5b), Bone Quality-Related Markers (HC, Pent), And Other Hormonal Assays Related to Calcium Metabolism (TSH, iPTH, ACTH)}

In all subjects, $\mathrm{BAP}, \mathrm{TRAP} 5 \mathrm{~b}, \mathrm{TSH}, \mathrm{PPTH}$ and $\mathrm{ACTH}$ values were within normal limits. Although HC levels in all subjects were normal, in 2 dancers (cases No. 6, 10) the levels of Pent were abnormally increased. Both two subjects also had a history of secondary amenorrhea (Table 3). No relationships between any of the measured parameters and fatigue fractures were found. The level of Pent was significantly negatively correlated with the lumbar spine BMD $(\mathrm{r}=-0.37, \mathrm{p}<$ 0.05).

(BAP: bone alkaline phosphatase, TRAP5b: tartrate-resistant acid phosphatase 5b, HC: homocystein, Pent: pentosidine, TSH: thyroid-stimulating hormone, iPTH: intact parathyroid hormone, ACTH: adrenocorticotropic hormone).

Table 3. Blood data.

\begin{tabular}{|c|c|c|c|c|c|c|c|}
\hline $\begin{array}{l}\text { Case } \\
\text { No. }\end{array}$ & $\begin{array}{l}\text { BAP } \\
(\mu \mathrm{g} / \mathrm{l})\end{array}$ & $\begin{array}{l}\text { TRAP5b } \\
(\mathrm{mU} / \mathrm{dl})\end{array}$ & $\begin{array}{c}\mathrm{HC} \\
(\mathrm{nmol} / \mathrm{ml})\end{array}$ & $\begin{array}{c}\text { Pent } \\
(\mu \mathrm{g} / \mathrm{ml})\end{array}$ & $\begin{array}{c}\text { TSH } \\
(\mu \mathrm{IU} / \mathrm{m})\end{array}$ & $\begin{array}{c}\text { iPTH } \\
(\mathrm{pg} / \mathrm{ml})\end{array}$ & $\begin{array}{r}\text { ACTH } \\
(\mathrm{pg} / \mathrm{ml})\end{array}$ \\
\hline 1 & 11.8 & 183 & 6.0 & 0.0186 & 1.46 & 42 & 14.4 \\
\hline 2 & 19.3 & 163 & 7.9 & 0.0332 & 1.56 & 23 & 10.3 \\
\hline 3 & 12.9 & 175 & 8.0 & 0.0308 & 3.61 & 26 & 19.3 \\
\hline 4 & 12.5 & 279 & 8.3 & 0.0407 & 1.71 & 30 & 12.7 \\
\hline 5 & 16.9 & 133 & 6.0 & 0.041 & 1.26 & 27 & 16.4 \\
\hline 6 & 12.2 & 167 & 5.5 & $0.0526^{*}$ & 1.59 & 22 & 9.9 \\
\hline 7 & 10.2 & 150 & 5.5 & 0.0268 & 3.22 & 20 & 10.3 \\
\hline 8 & 15.5 & 262 & 6.8 & 0.0361 & 1.4 & 15 & 12.7 \\
\hline 9 & 7.3 & 159 & 9.5 & 0.0359 & 1.88 & 37 & 25.5 \\
\hline 10 & 12.1 & 159 & 5.9 & $0.0522^{*}$ & 0.97 & 28 & 13.7 \\
\hline 11 & 9.7 & 274 & 7.4 & 0.0381 & 1.07 & 36 & 14.9 \\
\hline 12 & 14.2 & 159 & 7.3 & 0.0248 & 0.74 & 32 & 22 \\
\hline 13 & 15.2 & 291 & 5.1 & 0.0223 & 1.27 & 32 & 15.4 \\
\hline Normal & $2.9 \sim$ & $120 \sim$ & $3.7 \sim$ & $0.00915 \sim$ & $0.34 \sim$ & $10 \sim$ & $7.2 \sim$ \\
\hline range & 20.9 & 420 & 13.5 & 0.0431 & 4.04 & 65 & 63.3 \\
\hline
\end{tabular}




\section{Discussion}

Although epidemiologic data relating BMD to fractures in adolescents and premenopausal women are lacking, athletes doing weight-bearing sports usually have 5\% - 15\% higher BMDs than non-athletes [2]. There have been several reports regarding BMD in ballet dancers. Lichtenbelt et al. reported that the BMD in ballet dancers $(n=24)$ was significantly higher than that of a reference population [19]. On the other hand, Lucas reported that the BMD of ballet dancers ( $\mathrm{n}$ = 15) was not significantly different from the control subjects [20].

BMD and menstrual cycle relationship was also addressed. Warren et al. [21] and Kaufman et al. [22] demonstrated that BMD values in ballet dancers with regular menstrual cycles were not significantly different from those in control subjects; though in dancers after menopause the BMD levels were significantly lower. Recently, Amorin carried out a systematic review on prevalence of low BMD in female dancers and concluded that the published work cannot answer the fundamental question whether low BMD is actually more prevalent in female dancers [23]. BMD varies accordingly with age: it is different between in premenopausal and postmenopausal women. ISCD and ACSM recommended that BMD in premenopausal populations be expressed as Z-scores to compare individuals to age and sex-matched controls, and that Z-scores below -1.0 be considered as low bone density values.

Furthermore, an association between low BMD and stress fractures has been reported in female athletes including dancers [24] [25] [26]. However, BMD represents only one aspect of bone strength. Recent studies have clearly shown that bone quality also plays an important role and it has been thought that its involvement in establishing bone strength is approximately $30 \%$. Bone quality is maintained by collagen cross-links, whose formation affects tensile strength and post-yield properties of the bone. Recent studies have demonstrated that AGEs cross-link formation affects bone toughness and stiffness, and the elastic modulus was independent of other determinants of bone strength such as the mineral phase and microarchitecture [5] [6] [7].

Shiraki et al. divided bone fragility into three types based on BMD and bone quality involvement in postmenopausal population: 1) low BMD with normal bone quality; 2) bone quality degradation with normal BMD, and 3) low BMD with bone quality degradation, and investigated the risk of the fractures compared to the women who had normal BMD and bone quality. They concluded that fracture risk ratio was 3.6, 1.5, and 7.2 times higher, respectively [13].

Although bone quality is a dependent factor and plays an important role in bone strength in postmenopausal population, little attention has been paid to bone quality in young female athletes and there has been only one report available in the literature addressing this issue. Wakamatsu et al. reported that $\mathrm{HC}$ and Pent were not significantly different between lacrosse players who had experienced stress fracture and those who had not [27]. Since the menstrual abnormalities are estimated to occur in $20 \%$ of exercising females, with prevalence re- 
ported as high as $44 \%$ in ballet dancers and $51 \%$ in endurance runners [28] [29] [30] [31], the prevalence of high pentosidine levels could not be assumed low.

The present study demonstrated that in 2 out of 13 dancers, the levels of pentosidine were increased notwithstanding normal stress oxidative markers and bone metabolism markers including BMD. These subjects were also the two out of 3 subjects with secondary amenorrhea. It has been reported that Pent increases due to several factors such as aging, estrogen impairment, increased oxidative stress, diabetes and zero gravity [6]. We presumed that high Pent levels in the 2 subjects were caused by estrogen imbalances due to secondary amenorrhea, because other hormonal, metabolic or lifestyle-related diseases were not observed.

The present study has several limitations. It was a cross-sectional study, not case control or prospective study, and the number of subjects was small. The reasons why in 2 subjects pentosidine levels were high without decreased BMD remain unknown. We consider two potential explanations. First, the subjects with abnormally high levels of Pent also had low BMD due to secondary amenorrhea, but Pent levels had not yet recovered even BMD values normalized after re-start of menarche. This could have meant that bone quality recovery time is longer than that of BMD even after re-start of menstrual cycle. Second, high pentosidine levels were caused by secondary amenorrhea without any influence on BMD.

Timing of blood testing during menstrual cycle in the two subjects with higher pentosidine levels was not standardized. This is another limitation of the study, because there is evidence for cycle-related changes in other bone markers along phases of menstrual cycle [32] [33].

Notwithstanding the limitations, our study indicates that latent deterioration of bone quality can develop in female athletes who have experienced secondary amenorrhea but present with otherwise normal BMD and other calcium metabolic markers. Although we did not find any correlation between pentosidine levels and fatigue fractures, further prospective studies on the relationship between bone quality and stress fractures are necessary.

\section{Acknowledgements}

The authors thank the ballet dancers for participating in this study.

\section{Conflict of Interest Statement}

The authors declare that there is no conflict of interests regarding the publication of this article.

\section{References}

[1] National Institutes of Health Consensus Development Panel (2001) Osteoporosis Prevention, Diagnosis, and Therapy. JAMA, 285, 785-795. https://doi.org/10.1001/jama.285.6.785

[2] Nattiv, A., Loucks, A.B., Manore, M.M., Sanborn, C.F., Sundgot-Borgen, J. andWarren, M.P. (2007) American College of Sports Medicine Position Stand. The Fe- 
male Athlete Triad. Medicine \& Science in Sports \& Exercise, 39, 1867-1882.

[3] Matzkin, E., Curry, E.J. and Whitlock, K. (2015) Female Athlete Triad: Past, Present, and Future. Journal of the American Academy of Orthopaedic Surgeons, 23, 424-432. https://doi.org/10.5435/JAAOS-D-14-00168

[4] Mountjoy, M., Sundgot-Borgen, J., Burke, L., Carter, D., Constantini, N., Lebrun, C., Meyer, N., Sherman, R., Steffen, K., Budgett, R. and Ljungqvist, A. (2014) The IOC Consensus Statement: Beyond the Female Athlete Triad-Relative Energy Deficiency in Sport (RED-S). British Journal of Sports Medicine, 48, 491-497. https://doi.org/10.1136/bjsports-2014-093502

[5] Saito, M., Mori, S., Mashiba, T., Komatsubara, S. and Marumo, K. (2008) Collagen Maturity, Glycation Induced-Pentosidine, and Minerakization Are Increased Following 3-Year Treatment with Incadronate in Dogs. Osteoporosis International, 19, 1343-1354. https://doi.org/10.1007/s00198-008-0585-3

[6] Saito, M. and Marumo, K. (2010) Collagen Cross-Links as a Determinant of Bone Quality: A Possible Explanation for Bone Fragility in Aging, Osteoporosis, and Diabetes Mellitus. Osteoporosis International, 21, 195-214.

https://doi.org/10.1007/s00198-009-1066-Z

[7] Saito, M. and Marumo, K. (2015) Effects of Collagen Crosslinking on Bone Material Properties in Health and Disease. Calcified Tissue International, 97, 242-261. https://doi.org/10.1007/s00223-015-9985-5

[8] Viguet-Carrin, S., Roux, J.P., Arlot, M.E., Merabet, Z., Leeming, D.J., Byrjalsen, I.B., Delmas, P.D. and Bouxsein, M.L. (2006) Contribution of the Advanced Glycation End Product Pentosidine and of Maturation of Type I Collagen to Compressive Biomechanical Properties of Human Lumbar Vertebrae. Bone, 39, 1073-1079. https://doi.org/10.1016/j.bone.2006.05.013

[9] Viguet-Carrin, S., Garnero, P. and Delmas, P.D. (2006) The Role of Collagen in Bone Strength. Osteoporos International, 17, 319-336. https://doi.org/10.1007/s00198-005-2035-9

[10] Kuroda, T., Tanaka, S., Saito, M., Shiraki, Y. and Shiraki, M. (2013) Plasma Level of Homocysteine Associated with Severe Vertebral Fracture in Postmenopausal Women. Calcified Tissue International, 93, 269-275. https://doi.org/10.1007/s00223-013-9754-2

[11] McLean, R.R., Jacques, P.F., Selhub, J., Tucker, K.L., Samelson, E.J., Broe, K.E., Hannan, M.T., Cupples, L.A. and Kiel, D.P. (2004) Homocysteine as a Predictive Factor for Hip Fracture in Older Persons. The New England Journal of Medicine, 350, 2042-2049. https://doi.org/10.1056/NEJMoa032739

[12] Orimo, H., Nakamura, T., Hosoi, T., Iki, M., Uenishi, K., Endo, N., Ohta, H., Shiraki, M., Sugimoto, T., Suzuki, T., Soen, S., Nishizawa, Y., Hagino, H., Fukunaga, M. and Fujiwara, S. (2012) Japanese 2011 Guidelines for Prevention and Treatment of Osteoporosis-Executive Summary. Archives of Osteoporosis, 7, 3-20. https://doi.org/10.1007/s11657-012-0109-9

[13] Shiraki, M., Urano, T., Kuroda, T., Saito, M., Tanaka, D., Miyao-Koshizuka, M. and Inoue, S. (2008) The Synergistic Effect of Bone Mineral Density and Methylenetetrahydrofolate Reductase (MTHFR) Polymorphism (C677T) on Fractures. Journal of Bone and Mineral Metabolism, 26, 595-602. https://doi.org/10.1007/s00774-008-0878-9

[14] Shiraki, M., Kuroda, T., Tanaka, S., Saito, M., Fukunaga, M. and Nakamura, T. (2008) Nonenzymatic Collagen Cross-Links Induced by Glycoxidation (Pentosidine) Predicts Vertebral Fractures. Journal of Bone and Mineral Metabolism, 26, 
93-100. https://doi.org/10.1007/s00774-007-0784-6

[15] vanMeurs, J.B.J, Dhonukshe-Rutten, R.A.M, Pluijim, S.M.F., van der Klift,M., Jonge, R., Lindemans, J., Groot, L., Hofman, A., Witteman, J.C.M., van Leeuwen, J., Breteler, M.M.B., Lips, P., Pols, H.A.P. and Uitterlinden, A.G. (2004) Homocysteine Levels and the Risk of Osteoporotic Fracture. The New England Journal of Medicine, 350, 2033-2041. https://doi.org/10.1056/NEJMoa032546

[16] Abraham, G.E. (1978) The Normal Menstrual Cycle. In: Givens, J.R., Ed., Endocrine Causes of Menstrual Disorders, Year Book Medical Publishers, Inc., Chicago, 15-44.

[17] American Society of Reproductive Medicine Practice Committee (2008) Current Evaluation of Amenorrhea-Has an Update (Reviewed June 2008). Fertility and Sterility, 90, s219-225.

[18] Nishizawa, N., Nakamura, T., Ohta, H., Kushida, K., Gorai, I., Shiraki, M., Fukunaga, M., Hosoi, T., Miki, T., Chaki, O., Ichimura, S., Nakatsuka, K. and Miura, M. (2005) Guidelines for the Use of Biochemical Markers of Bone Turnover in Osteoporosis (2004). Journal of Bone and Mineral Metabolism, 23, 97-104. https://doi.org/10.1007/s00774-004-0547-6

[19] Lichtenbelt, W.D., Fogelholm, M., Ottenheijm, R. and Westerterp, K.R. (1995) Physical Activity, Body Composition and Bone Density in Ballet Dancers. British Journal of Nutrition, 74, 439-451. https://doi.org/10.1079/BJN19950150

[20] Lucas, A.F., Akers, J.D. and Davy, B.M. (2010) Energetic Efficiency, Menstrual Irregularity, and Bone Mineral Density in Elite Professional Female Ballet Dancers. Journal of Dance Medicine \& Science, 14, 146-154.

[21] Warren, M.P., Brooks-Gunn, J., Fox, R.P., Holderness, C.C., Hyle, E.P. and Hamilton, W.G. (2002) Osteopenia in Exercise-Associated Amenorrhea Using Ballet Dancers as a Model: A Longitudinal Study. The Journal of Clinical Endocrinology \& Metabolism, 87, 3162-3168. https://doi.org/10.1210/jcem.87.7.8637

[22] Kaufman, B.A., Warren, M.P., Dominguez, J.E., Wang, J., Heymsfield, S.B. and Pierson, R.N. (2002) Bone Density and Amenorrhea in Ballet Dancers Are Related to a Decreased Resting Metabolic Rate and Lower Leptin Levels. The Journal of Clinical Endocrinology \& Metabolism, 87, 2777-2783. https://doi.org/10.1210/jcem.87.6.8565

[23] Amorim, T., Wyon, M., Maia, J., Machado, J.C., Marques, F., Metsios, G.S., Flouris, A.D. and Koutedakis, Y. (2015) Prevalence of Low Bone Mineral Density in Female Dancers. Sports Medicine, 45, 257-268. https://doi.org/10.1007/s40279-014-0268-5

[24] Beck, T.J., Ruff, C.B., Shaffer, R.A., Betsinger, K., Trone, D.W. and Brodine, S.K. (2000) Stress Fracture in Military Recruits: Gender Differences in Muscle and Bone Susceptibility Factors. Bone, 27, 437-444. https://doi.org/10.1016/S8756-3282(00)00342-2

[25] Bennell, K.L., Malcolm, S.A., Thomas, S.A., Reid, S.J., Brukner, P.D., Ebeling, P.R. and Wark, J.D. (1996) Risk Factors for Stress Fractures in Track and Field Athletes. A Twelve-Month Prospective Study. The American Journal of Sports Medicine, 24, 810-818. https://doi.org/10.1177/036354659602400617

[26] Kelsey, J.L., Bachrach, L.K., Procter-Gray, E., Nieves, J., Greendale, G.A., Sowers, M., Brown, B.W.J., Matheson, K.A., Crawford, S.L. and Cobb, K.L. (2007) Risk Factors for Stress Fracture among Young Female Cross-Country Runners. Medicine and Science in Sports and Exercise, 39, 1457-1463. https://doi.org/10.1249/mss.0b013e318074e54b

[27] Wakamatsu, K., Sakuraba, K., Suzuki, Y., Maruyama, A., Tsuchiya, Y., Shikakura, J. and Ochi, E. (2012) Association between the Stress Fracture and Bone Metabolism/ 
Quality Markers in Lacrosse Players. Open Access Journal of Sports Medicine, 3, 67-71.

[28] Greydanus, D.E. and Patel, D.R. (2002) The Female Athlete. Before and beyond Puberty. Pediatric Clinics of North America, 49, 553-580.

https://doi.org/10.1016/S0031-3955(02)00005-6

[29] Shangold, M., Rebar, R.W., Wentz, A.C. and Schiff, I. (1990) Evaluation and Management of Menstrual Dysfunction in Athletes. JAMA, 263, 1665-1669. https://doi.org/10.1001/jama.1990.03440120087043

[30] Torstveit, M.K. and Sundgot-Borgen, J. (2005) The Female Athlete Triad: Are Elite Athletes at Increased Risk? Medicine and Science in Sports and Exercise, 37, 184-193. https://doi.org/10.1249/01.MSS.0000152677.60545.3A

[31] Torstveit, M.K. and Sundgot-Borgen, L. (2005) Low Bone Mineral Density Is Two to Three Times More Prevalent in Non-Athletic Premenopausal Women than in Elite Athletes: A Comprehensive Controlled Study. British Journal of Sports Medicine, 39, 282-287. https://doi.org/10.1136/bjsm.2004.012781

[32] Kalyan, S. and Prior, J.C. (2010) Bone Changes and Fracture Related to Menstrual Cycles and Ovulation. Critical Reviews in Eukaryotic Gene Expression, 20, 213-233. https://doi.org/10.1615/CritRevEukarGeneExpr.v20.i3.30

[33] Nielsen, H.K., Brixen, K., Bouillon, R. and Mosekilde, L. (1990) Changes in Biochemical Markers of Osteoblastic Activity during the Menstrual Cycle. The Journal of Clinical Endocrinology and Metabolism, 70, 1431-1437. https://doi.org/10.1210/jcem-70-5-1431

Submit or recommend next manuscript to SCIRP and we will provide best service for you:

Accepting pre-submission inquiries through Email, Facebook, LinkedIn, Twitter, etc. A wide selection of journals (inclusive of 9 subjects, more than 200 journals)

Providing 24-hour high-quality service

User-friendly online submission system

Fair and swift peer-review system

Efficient typesetting and proofreading procedure

Display of the result of downloads and visits, as well as the number of cited articles

Maximum dissemination of your research work

Submit your manuscript at: http://papersubmission.scirp.org/

Or contact ojo@scirp.org 